\title{
Williams-Beuren syndrome: Determination of deletion size using quantitative real-time PCR
}

\author{
CORNELIA SCHUBERT and FRANCO LACCONE \\ Institute of Human Genetics, Georg-August University, Heinrich Dueker Weg 12, 37073 Goettingen, Germany
}

Received April 6, 2006; Accepted June 13, 2006

\begin{abstract}
Williams-Beuren syndrome (WBS) is a rare genetic disorder (1/20000-50000) and is usually caused by a 1.5- to $1.8-\mathrm{Mb}$ heterozygous deletion on chromosome 7q11.23. At least 25 genes have been identified in the deletion region in WBS patients, which is flanked by large low-copy-repeat sequences $(>320 \mathrm{~kb}$ ). By using FISH as well as microsatellite analysis, it is not possible to get a precise identification of the size of the deletion. For determining the deletion size, we developed a reliable quantitative PCR approach. Our assay screens $2.5 \mathrm{Mb}$ of the WBS region in 100- to 300-kb intervals. This methodology has been tested in DNA samples of 65 patients with the clinical suspicion of WBS. In every case we were able to exclude or to identify the presence of a deletion and to determine its size. Deletion size varied from $0.2 \mathrm{Mb}$ to $2.5 \mathrm{Mb}$. The 2.5-Mb rearrangement represents the largest deletion described at present and it was detected in a severely affected patient. We report the detection efficiency of this new system and the genotype/phenotype correlation.
\end{abstract}

\section{Introduction}

Williams-Beuren syndrome (WBS) is a rare genetic disorder $(1 / 20,000-50,000)$ caused by a heterozygous deletion on chromosome 7q11.23. WBS patients display vascular stenosis, weakness of connective tissue, specific facial characteristics, short stature and mental retardation. Usually, WBS occurs sporadically, but a few cases of autosomal-dominant inheritance have been reported $(1,2)$. More than 25 genes have been identified in the deletion region of WBS flanked by three large low-copy-repeat sequences (LCR) (>320 kb), arranged to LCR blocks A, B and C (3). These LCRs share high similarity of nucleotide sequence with a liability to mispairing and unequal crossover leading to deletions $(4,5)$. One-third of the deletions occur because of intrachromosomal rearrange-

Correspondence to: Dr Cornelia Schubert, Institute of Human Genetics, University of Goettingen, Heinrich Dueker Weg 12, 37073 Goettingen, Germany

E-mail: cschube@gwdg.de

Key words: Williams-Beuren syndrome, quantitative PCR, genedosage analysis ments (6). Common deletions in WBS patients span a genomic region of $1.5 \mathrm{Mb}$ with breakpoints within the centromeric and medial LCR block B (7-9). Atypical deletions with smaller and larger deletion sizes have also been reported $(10,11)$. Bayes et al reported that $\sim 5 \%$ of typical WBS patients have a deletion of $1.84 \mathrm{Mb}$ caused by recombination between LCR block A copies (9). Furthermore there were reports on patients displaying a deletion $<1 \mathrm{Mb}$, spanning from $E L N$ to D7S1870 excluding the genes STX1A and FZD9 (12). The full spectrum of WBS disease was also found in a patient with a deletion of $950 \mathrm{~kb}$ with centromeric and telomeric breakpoints between ELN and STX1A and distal to D7S489A, respectively (13). Karmiloff-Smith et al described two patients with an atypical spectrum of WBS disease: one patient with a deletion size of $\sim 850 \mathrm{~kb}$ within the common WBS deletion was affected only by supravalvular aortic stenosis. The second one with a typical deletion size of $1.8 \mathrm{Mb}$ showed a very high verbal score (close to the normal population), but only poor outcome in non-verbal reasoning and spatial scores (11). A paracentric inversion $(1.5 \mathrm{Mb})$ on chromosome 7 has been reported in patients with a subset of WBS symptoms. In some of these patients the inversion was inherited by one of the healthy parents. This inversion was also observed in four out of twelve parents transmitting the disease-related chromosome to their child with classical WBS deletion (2). Recently, a case report described a patient with a duplication of the WBS region, who had a severe expressive-language delay and attention deficit hyperactivity syndrome (ADHS) (14).

These data strongly indicate a phenotypic variability depending on the size of deletion in the WBS region. The FISH- and/or microsatellite analyses, as the most widespread analysis strategies for deletion detection in WBS patients allow, however, only an approximate estimation of the deletion size and therefore of the affected genes. For a more precise determination of the deleted genes and identification of the deletion size in WBS patients, we developed a quantitative PCR approach (qPCR) that scans $2.5 \mathrm{Mb}$ of the WBS deletion region with a resolution of $100-300 \mathrm{~kb}$.

\section{Patients and methods}

Patients. DNA samples of 65 patients referred to the Institute of Human Genetics, University of Goettingen, Germany, with a strong clinical indication of having Williams-Beuren syndrome, were selected for analysis by quantitative PCR. Within the framework of routine-diagnostic 54 out of 65 
Table I. List of generated PCR primer pairs located within the WBS deletion region on chromosome 7.

\begin{tabular}{|c|c|c|c|c|c|c|}
\hline Amplicon & $\begin{array}{l}\text { Primer } \\
\text { name }\end{array}$ & Sequences, forward & $\begin{array}{l}\text { Genome } \\
\text { position }\end{array}$ & Sequences, reverse & $\begin{array}{l}\text { Genome } \\
\text { position }\end{array}$ & $\begin{array}{l}\text { Product } \\
\text { length } \\
\text { (bp) }\end{array}$ \\
\hline 1 & WBS161 & TTCATCCCCACTCTGCCCACTGC & $7: 71448573$ & GCAACAGCCACACACTCTGTCTGCC & 7:71448805 & 233 \\
\hline 2 & WBS522 & TTGCTTCCTCTCCCAGCCTTTCACC & 7:71810506 & ACAGAAGGAGGGGCCAGGGAAGAG & 7:71810689 & 184 \\
\hline 3 & WBS618 & CTGTCAAAAGGCTTCTGTGCTGGGG & 7:71905607 & CAGAAGGAAGGTGGAGGGCAGGAAC & 7:71905853 & 247 \\
\hline 4 & WBS884 & СТСССАССССТTCССGCCAC & $7: 72172733$ & TGGGCGAGGTCCGTTTTGGC & 7:72172913 & 181 \\
\hline 5 & WBS967 & ACCGGCCCTTCCCAGACCTGAC & $7: 72255197$ & TGTCCCTCTGTGCCCTCCCTGC & 7:72255448 & 252 \\
\hline 6 & WBS1016 & CAACGGAAGGTGAAGGGAGGAGCA & 7:72303142 & GCAGGACGGGGCAGGACAGAAG & 7:72303385 & 244 \\
\hline 7 & WBS1393 & GCAATGGCTGATGGGACAAGTGAGG & $7: 72680575$ & CCCCAGCATCAGTCTCCATCCCC & $7: 72680813$ & 239 \\
\hline 8 & WBS1610 & CGGGAAATACTGGCGGATAAGGAGC & $7: 72897561$ & CCAGATGGACTTTTAGCGCAGGGG & 7:72897815 & 255 \\
\hline 9 & WBS1826 & CACAGACGGCCTCCACCTCCATTC & $7: 73113343$ & GGCGCCAGGTCTCCCATAGCAAC & 7:73113554 & 212 \\
\hline 10 & WBS2292 & AAGTGGCTAATTTGACACCGACGCG & 7:73581121 & TTACGAAAACTGAGGCATGCGGTCC & 7:73581324 & 204 \\
\hline 11 & WBS2447 & GCAAGCAAGCAAGCCTGAG & $7: 73735062$ & TGCAGAATGGCTCCAGAGGT & 7:73735278 & 217 \\
\hline 12 & WBS2637 & TAGACCCGCCTTCCCCTCCTGG & $7: 73925297$ & TTGACGACTGGGCAGAGGCGC & 7:73925481 & 185 \\
\hline 13 & WBSSOX9 & GGAGGATGGACGAAGACTGGTGGG & 17:67629800 & CTCGGTTTCTCCCTTGCCCCATC & $17: 67629980$ & 181 \\
\hline
\end{tabular}

Stated are the primer sequences, the direction of primer, the position of the first base of primer on chromosome 7 (Assembly May 2004, http://genome.ucsc.edudatabase) and length of PCR product. Primer-pair WBS_SOX9 (no. 13) acts as reference probe.

patients had been previously screened on WBS by FISH and/or microsatellite analysis. Concentration of DNA was determined by measurement of optical density at $260 \mathrm{~nm}$ and probes were diluted to a concentration of $50 \mathrm{ng} / \mu 1$, stored at $4^{\circ} \mathrm{C}$ and mixed immediately before use.

Primers and probes. Sequences for primer design were taken from the USCS database sequence of chromosome 7 from position 71.449.000 to 73.925.000, masked by the Repeat Masker program (http://genome.ucsc.edu/cgi-bin/hgGateway). Non-repetitive sequence-fragments in $100-300 \mathrm{~kb}$ intervals along the WBS deletion region $(\sim 2.5 \mathrm{Mb})$ were chosen for designing PCR primer pairs using the software vector $\mathrm{NTI}^{\circledR}$ (Invitrogen, La Jolla). Thirteen PCR primer pairs were selected to generate amplicons as previously described (15). As reference amplicon a sequence region located within the SOX 9 gene on chromosome 17 was used. Primers selected for the generation of amplicons satisfying the requirements as well as the amplicons themselves were then analyzed by BLAT search. Only amplicons and corresponding primers that show singularity were selected for the quantitative PCR. Primers were obtained from Operon ${ }^{\circledR}$ (www.operon.com). Sequences and PCR conditions of selected primers and amplicons are shown in Table I.

Quantitative analysis and standard curves. The analysis protocol was performed as described (16). The reaction mixture contained $0.5 \mathrm{mM}$ of each primer and $5 \mu \mathrm{l}$ of $2 \mathrm{xQuanti}$ Tect $\mathrm{SYBR}^{\circledR}$-Green Master mix (Qiagen Inc., www.qiagen.com) which includes HotStarTaq ${ }^{\circledR}$ DNA-polymerase in an optimized buffer, dNTP mix (with dUTP additive), SYBR-Green I fluorescent dye, and ROX dye as a passive reference. The wells of a 384-well plate were loaded with control DNA of an unaffected individual in a final concentration of $10.0 \mathrm{ng} / \mu 1$, $5.0 \mathrm{ng} / \mu 1,2.5 \mathrm{ng} / \mu 1$ and $1.25 \mathrm{ng} / \mu 1$, respectively, a non-template control (NTC) and DNA of patients in a final concentration of $10 \mathrm{ng} / \mu \mathrm{l}$ in a total volume of $10 \mu \mathrm{l}$. Each patient was tested at least twice. PCR conditions were $95^{\circ} \mathrm{C}$ for $15 \mathrm{~min}$, and 40 cycles at $94^{\circ} \mathrm{C}$ for $15 \mathrm{sec}$, and $60^{\circ} \mathrm{C}$ for $30 \mathrm{sec}$ followed by a $72^{\circ} \mathrm{C}$ elongation period for $1 \mathrm{~min}$. To identify unspecific amplification products, a melting curve analysis of the product was performed after finishing amplification by high-resolution data collection during an incremental temperature increase from $60^{\circ} \mathrm{C}$ to $95^{\circ} \mathrm{C}$ with a ramp rate of $0.2^{\circ} \mathrm{C} / \mathrm{sec}$.

Separate standard curves of diluted control DNA (with concentrations of $10.0 \mathrm{ng} / \mu 1,5.0 \mathrm{ng} / \mu 1,2.5 \mathrm{ng} / \mu 1$ and $1.25 \mathrm{ng} /$ $\mu 1)$ were constructed for each tested primer pair. The fractional cycle-number $(\mathrm{Ct})$ of a probe, where the measured fluorescence reaches a fixed threshold is directly related to the amount of input DNA. A higher or lower starting copy-number of input DNA as a sign for a deletion or a duplication will result in an earlier or later increase of fluorescence, respectively. The amount of the target DNA in test samples was quantified by measuring its $\mathrm{Ct}$ value in comparison to the corresponding logarithmic standard curve plot for linear interpolation of control DNA and a relative starting copy number was calculated. The absolute starting copy number of the several test loci is given by the ratio of relative starting copy number of the test locus in the WBS region to the SOX9 reference locus (Fig. 1A and B). As an example, the absolute starting copy numbers of the WBS test loci of a heterozygous deletion in the WBS region ranging from the amplicons WBS884 to WBS2292 (1.4 Mb) and from WBS618 to WBS2292 (1.6 Mb) are shown in Fig. 2.

For assigning limits of the copy number range to identify haploidy or diploidy, standard values were ascertained from 15 healthy controls by measuring the absolute starting copy number with 10 ng DNA and with a simulating deletion, i.e. $5 \mathrm{ng}$ of input DNA. Mean-values of 0.99 and 0.46 with a standard deviation of 0.15 and 0.12 indicate a diploidy or haploidy, respectively (Fig. 1C). 
A:

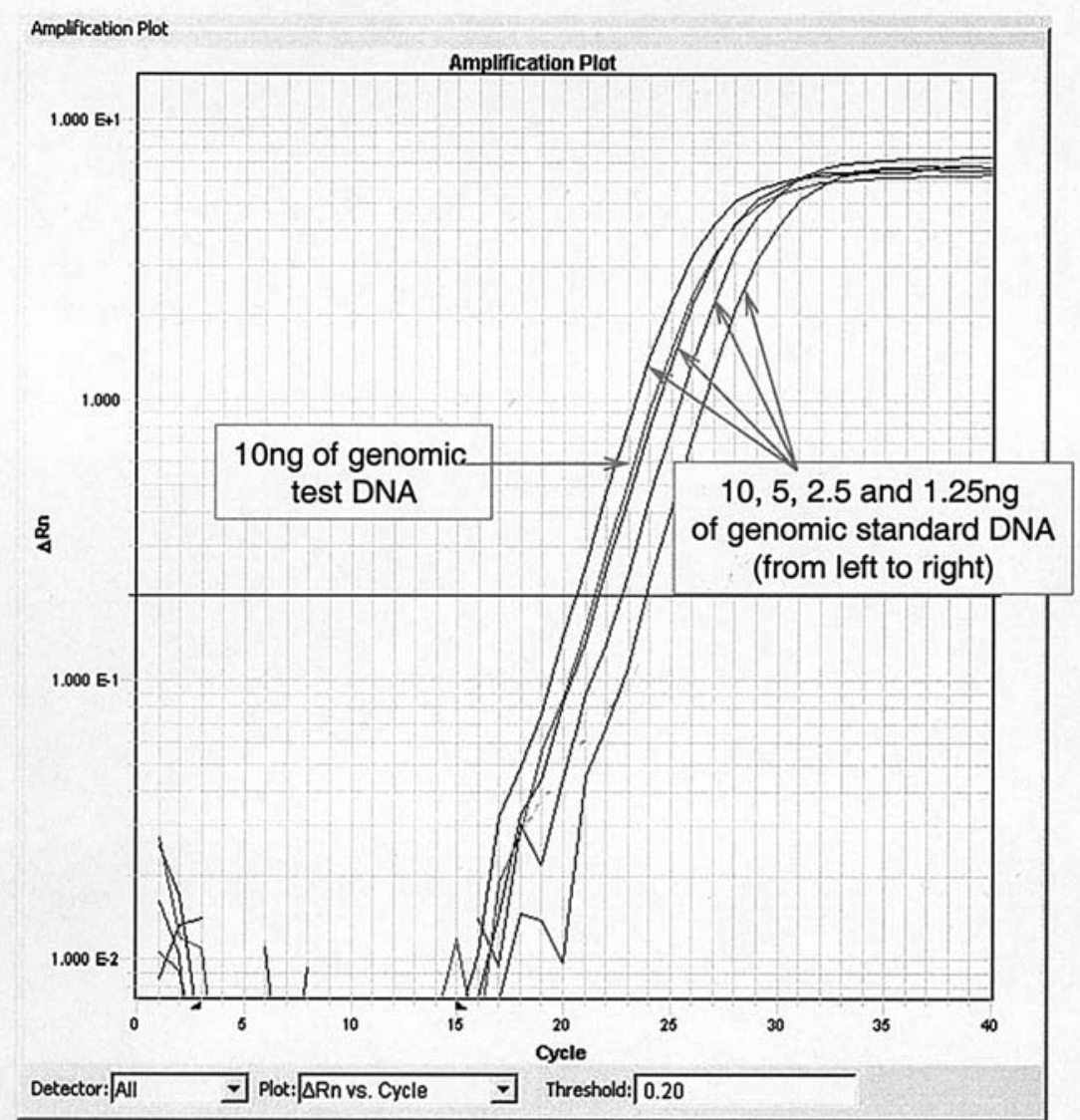

B:

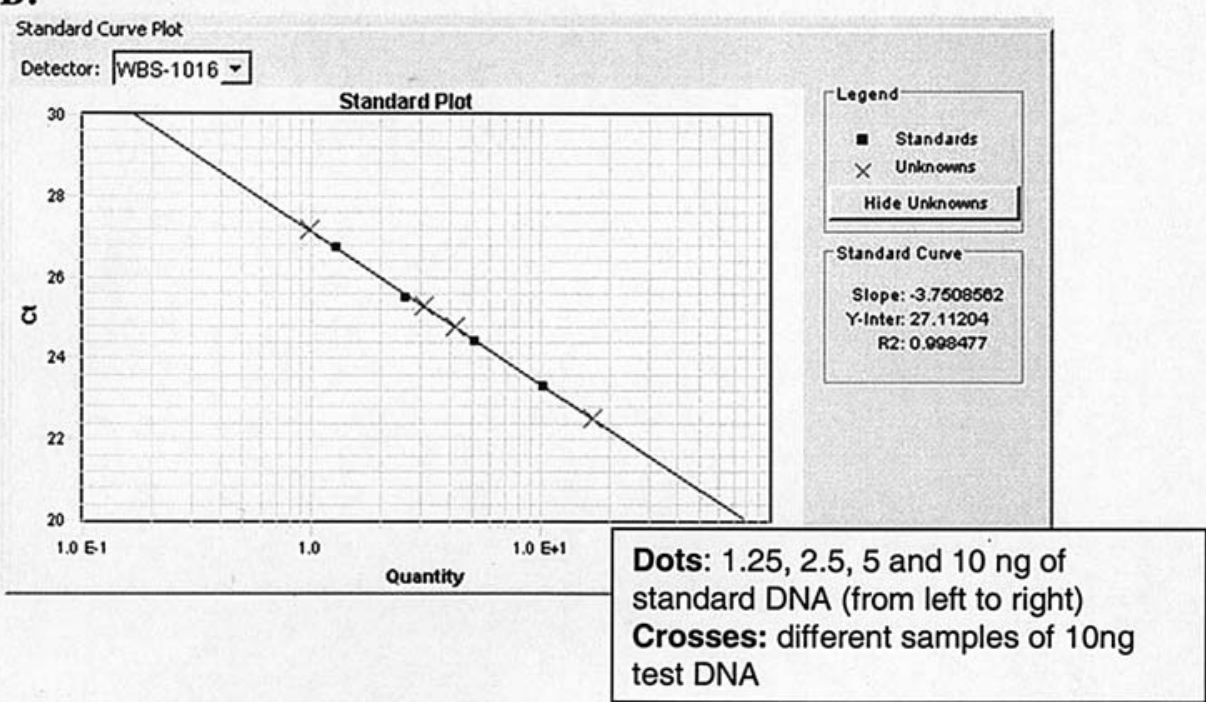

C:

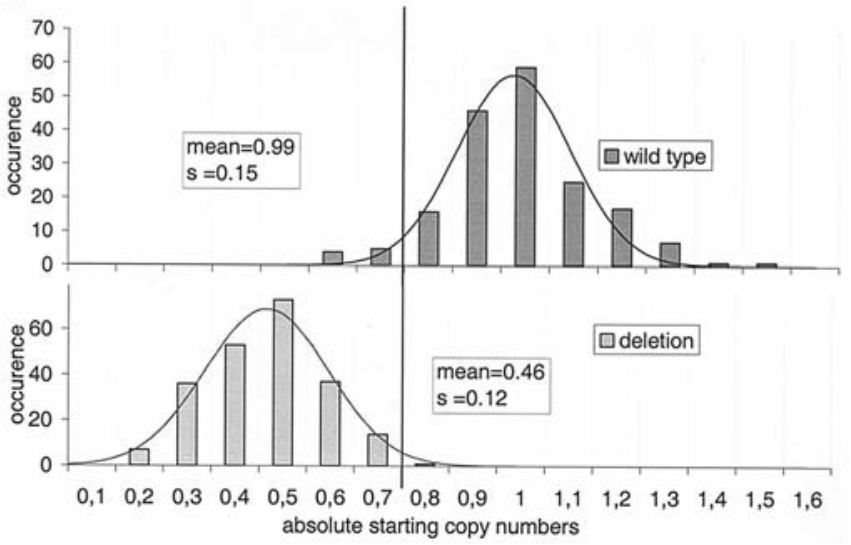

Figure 1. A, exemplary depiction of amplification curves for analysis of the WBS_967 locus. Dark lines, amplification of 10, 5, 2.5 and $1.25 \mathrm{ng}$ of standard DNA (from left to right); light line, amplification of $10 \mathrm{ng}$ test DNA. In comparing to the amplification of the SOX9 locus of the same test DNA a deletion in the WBS_967 locus is apparent (amplification curves of SOX9 locus are not shown). B, exemplary depiction of a logarithmic standard curve of WBS_1016 locus for calculating the starting copy number from the $\mathrm{Ct}$ values of test DNA. - and $\mathrm{x}$, amplifications of different standard DNA amounts $(1.25,2.5,5$ and $10 \mathrm{ng}$, from left to right) and of the itemised test DNA, respectively. C, assigned limits of starting copy number values for identifying diploid or haploid genotypes, amplicons with a starting copy number $>0.7$ were identified as wild-type and $<0.7$ as a heterozygous deletion. 
Table II. Summary of variable deletion sizes in patients with the strong clinical suspicion of WBS in relating to the heterozygous deleted genes (for graphical details see Fig. 3).

$\begin{array}{lll}\text { Deletion in WBS region } \quad \text { No. of deletion-positive patients } & \begin{array}{l}\text { Deleted genes } \Rightarrow \text { size of the deletion } \\ \text { (number of genes) }\end{array} \% \text { of deletion-positive patients }\end{array}$

\begin{tabular}{lclr}
\hline qPCR 884-2292 & 8 & TRIM5OA to GTF2I $\Rightarrow 1.4 \mathrm{Mb}(20)$ & $38 \%$ \\
qPCR 618-2292 & 7 & $S T A 3 L 1$ to GTF2I $\Rightarrow 1.7 \mathrm{Mb}(22)$ & $33 \%$ \\
qPCR 618-2447 & 3 & $S T A 3 L 1$ to GTF2IRD2 $\Rightarrow 1.8 \mathrm{Mb}(24)$ & $14 \%$ \\
qPCR 884-2447 & 1 & TRIM50A to GTF2IRD2 $\Rightarrow 1.6 \mathrm{Mb}(22)$ & $5 \%$ \\
qPCR 161-2637 & 1 & $S B D S P$ to $G T F 2 I R D 2 B \Rightarrow 2.5 \mathrm{Mb}(27)$ & $5 \%$ \\
qPCR 1610-1826 & 1 & $E L N$ to $C Y L N 2 \Rightarrow 0.2 \mathrm{Mb}(5)$ & $5 \%$ \\
no deletion & $44 / 65$ & & \\
\hline
\end{tabular}

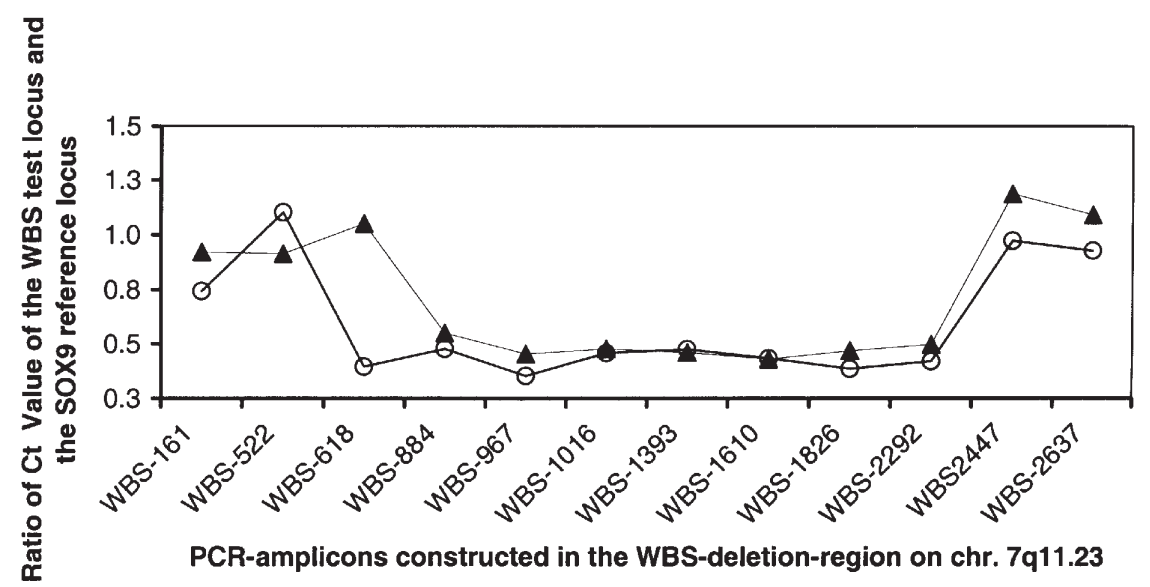

Figure 2. Measurement of absolute starting copy number in two individuals. $\mathbf{\Delta}$, an individual with a heterozygous deletion inside the WBS region ranging from amplicons WBS_884 to WBS_2292; 0, an individual with a heterozygous deletion inside the WBS region ranging from amplicons WBS_618 to WBS_2292. The absolute starting copy numbers are given as ratio of Ct value of the WBS test locus and the SOX9 reference locus

\section{Results}

Out of 65 patients, $21(32 \%)$ were found to have a deletion in the WBS region. Eight patients (38\% of deletion-positive patients) had a deletion of $\sim 1.4 \mathrm{Mb}$ in size. At least 20 genes were mapped within this interval ranging from TRIM50A to GTF2I including the genes ELN and LIMK1. Seven patients (33\% of deletion-positive patients) displayed a 1.7-Mb deletion, spanning 22 genes from STA3L1 to GTF2I. Three other patients ( $14 \%$ of deletion-positive patients) have a $1.8-\mathrm{Mb}$ deletion of 24 genes ranging from $S T A 3 L 1$ to GTF2IRD2. A $1.6-\mathrm{Mb}$ deletion with 22 affected genes was shown by one patient (5\% of deletion-positive patients) ranging from TRIM50A to GTF2IRD2. Another patient presented a deletion of $\sim 2.5 \mathrm{Mb}$ encompassing at least 27 genes from SPDSP to GTF2IRD2B. A second patient had a small deletion of $200 \mathrm{~kb}$ around the ELN gene affecting 5 genes: ELN, LIMK1, EIFH4H, RFC2 and WBSCR5 (WBSCR: Williams-Beuren syndrome chromosomal region).

Our collective has been previously investigated by an independent method (FISH or microsatellite analysis), which supported the results of our analysis. There were no inconsistencies between the results of FISH/microsatellite analyis and qPCR. We did not detect any duplication of WBS regions (Table II and Fig. 3).

In our collective only raw clinical data from most patients were available, such as heart defect, hoarse voice, hypercalcaemia, signs of dysmorphic facial, psychomotor or mental retardation and abdominal malformations. Unfortunately, detailed information about cognitive abilities (IQ values), defects in visual-spatial-constructive cognition and behavioural features were not available. The genotype-phenotype analysis for patients with deletions between 1.4 and $1.8 \mathrm{Mb}$ did not give any correlation, probably due to the limited available clinical data. One patient with a small deletion of $200 \mathrm{~kb}$ affecting five genes around $E L N$ displayed only aortic stenosis clinically. A second patient with a deletion of $\sim 2.5 \mathrm{Mb}$ demonstrated a severe phenotype of WBS. He displayed psychomotor retardation with distinct disturbance of equilibrium. He was able to walk, but had problems in climbing and jumping. Furthermore, he did not develop any speech and had strong mental retardation with autistic behaviour in high gear; unfortunately no values of IQ testing were available. In the first year of life he developed epilepsy, which disappeared as he became older. Furthermore, he had a short stature with the typical facial stigmata of WBS, supravalvular 


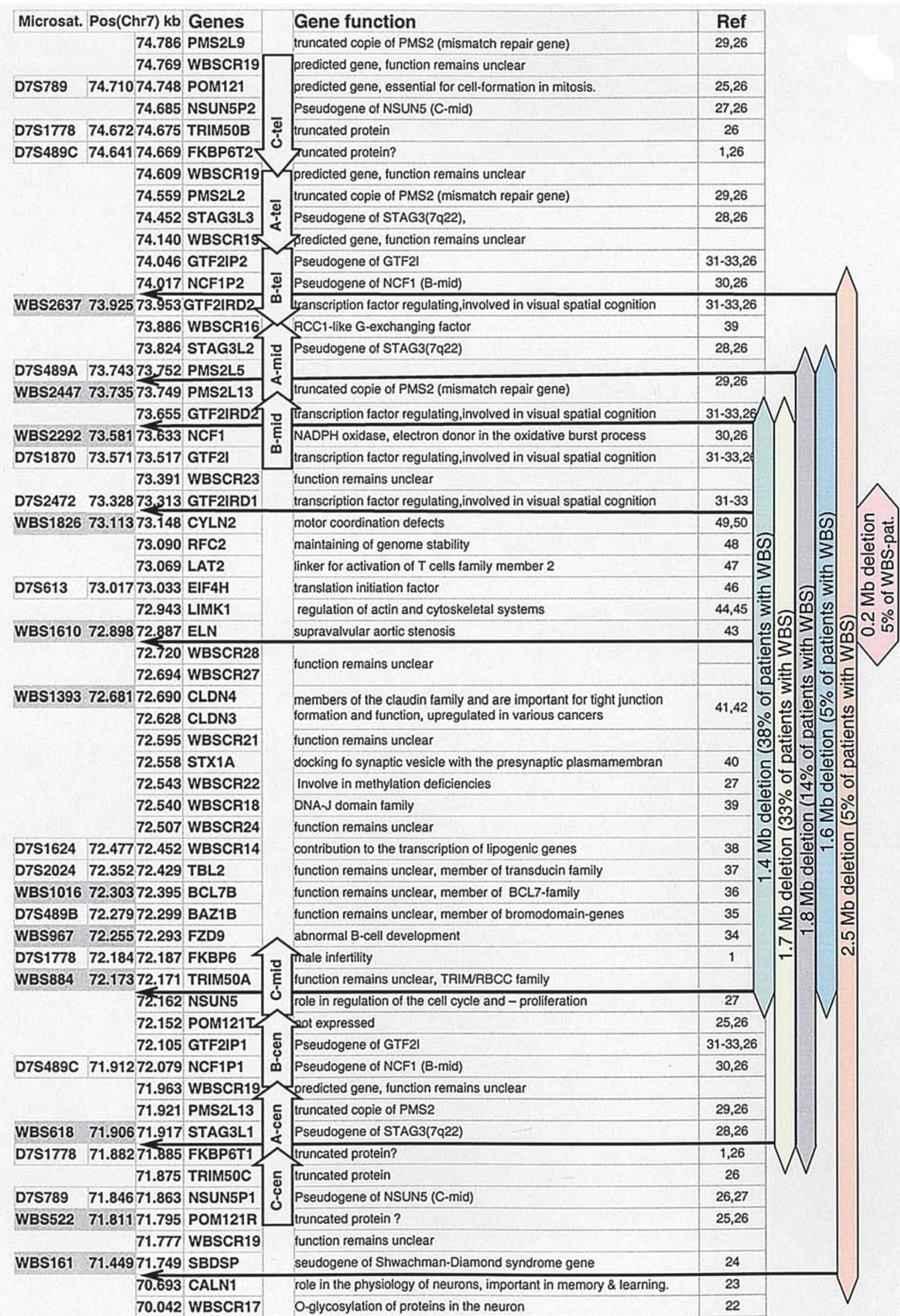

Figure 3. Graphic of chromosome 7q11.23 with the deletion region of Williams-Beuren syndrome. Magnification of the region from nucleotides 7174.000.000 showing the twelve amplicons as grey bars that were assessed by qPCR in this study. The known sts markers located in the WBS region are above and underneath the amplicons. The known genes, pseudogenes and hypothetical genes (depicted to their identification code) and their known or putative function are given aside. The vertical bars at the right side of the figure indicate the deleted regions of different sizes in our patients. 
aortic stenosis and did not develop the typical behaviour of WBS patients, such as friendliness to strangers, party chatter or musical talent.

\section{Discussion}

In the present study, DNA samples of 65 patients with the clinical symptoms of WBS were investigated for deletions in the genomic region of WBS by using quantitative real-time PCR (qPCR). This method allows not only the detection of a deletion/duplication but also the determination of its size.

In earlier publications it was shown that qPCR is a reliable technique for proving monosomies, trisomies, gene expression quantification in different tissues as well as subtelomeric deletions $(17,18)$. The principle of this technique is based on fluorescence measurement of DNA suspension. Thereby, the quantification is obtained by ratio metric measurements of the test locus. As standard, an interpolated curve of a reference locus with known DNA concentration is used.

Along the WBS region 12 amplicons have been generated. Individuals, in which the input DNA concentration of one amplicon was reduced by $50 \%$, had a heterozygous deletion of the corresponding genomic region. By application of the method described in this paper, the accuracy of the deletion size could be resolved up to $100-300 \mathrm{~kb}$. As reference-locus a sequence region positioned inside the SOX 9 gene was selected. Deletions of the SOX 9 gene result in severe Campomelic syndrome or are incompatible with life (19). Compared to conventional techniques such as FISH or microsatellite investigations we were able to get a higher resolution of the deletion size by using qPCR. Moreover, qPCR informative STS markers and parental DNA are not necessary. qPCR allows subsequently the analysis of sub-regions of microdeletions and the refinement of the deletion size. The method enables a high throughput rate of test samples by similar or even lower effort and cost compared to microsatellite or FISH investigations.

Primer positioning. The deletion locus of the WBS region is flanked by low-copy-repeat sequences (LCR) (>320kb), which share high similarity of nucleotide sequence. This peculiarity of the WBS region, which is likely an important factor in the mutational mechanisms (20), makes a high demand on primer positioning and amplicon-generating within the WBS region. In our analysis, we positioned our amplicons by BLAT-search within the nucleotide sequence of chromosome 7 from position 71.449.000 to 73.925.000, masked by the Repeat Masker program (http://genome.ucsc.edu/cgi-bin/hgGateway). Due to these repetitive sequence segments a positioning of primers at constant intervals is not possible because of unspecific or redundant amplifications.

In the present study, we have found that DNA probes older than 5 years occasionally show false positive results. This was mainly elicited by the presence of multiple discontinuous deletions along the chromosomal region. Furthermore, the detection of these single deletions was not reproducible in following tests. In such cases, a new blood sample was required and the analysis was repeated with new DNA samples. Reanalysis with freshly prepared DNA has not yet detected any deletions. It is highly recommendable in case of quantification of gene dosage to use highly qualitative and freshly extracted DNA in order to avoid false positive results.

For a routine application of this qPCR approach in WBS diagnostic, we recommend as a first step the analysis of amplicons WBS161, WBS618, WBS1610, WBS2447 and WBS2637 (Table I). The identification of a deletion can then be followed by a refinement of the deletion size by using additional amplicons.

Genotype-phenotype correlation. qPCR allows a more accurate definition of the deletion size for genotype-phenotype correlation studies. It is even possible to get more information about the pathogenetic role of single affected genes.

To our knowledge, this is the fist description of a patient with WBS having a deletion of $2.5 \mathrm{Mb}$. A conventional chromosome analysis of the patient yielded a numerical and structural normal karyotype with no apparent interstitial deletion on chromosome 7. FISH analysis detected a heterozygous deletion of the WBS region. The deletion size of $2.5 \mathrm{Mb}$ in this patient encompasses the typical WBS region and additionally all centromeric and medial LCR blocks A-C. Usually, breakpoints of WBS deletions in most patients are located within the centromeric and medial LCR block B (7-9). The deletion in this patient, in comparing to the most frequent deletion size of 1.5-1.8 $\mathrm{Mb}$, comprises the additional genes GTF2IRD2B and WBSCR 16, located between the LCR blocks A-mid and B-tel and further pseudogenes and genes with only partial open reading frame (ORF), located within the LCR blocks A-cen and C-cen and A-mid (Fig. 3).

In the current analysis, this patient presents a heterozygous deletion in all of our amplicons within the WBS region. It is possible that the deletion size may be even more than 2.5 Mb. In a further study we will extend the genomic region of our quantitative PCR analysis for precise deletion size ascertainment.

The second patient with an unusual size of deletion of $200 \mathrm{~kb}$ is affected only by a heart defect. This correlation has been previously reported for other patients with small deletion around the ELN gene (21).

In conclusion, qPCR analysis is a valid method for detecting deletions of the WBS region and for a more precise definition of the deletion size. Furthermore, this method allows the processing of several patients within the same run. On the basis of a more detailed clinical evaluation of the patients, the reported qPCR method should allow a more accurate genotype-phenotype correlation.

\section{Acknowledgements}

Many thanks to S. Barnikol for technical support and W. Engel for financial support and scientific discussion. Electronic databases: http://genome.ucsc.edu; http://genome.ucsc.edu/ cgi-bin/hgBlat; http://genome.ucsc.edu/cgi-bin/hgGateway (Assembly May 2004); http://www.ncbi.nlm.nih.gov/mapview/ maps.cgi.

\section{References}

1. Metcalfe K, Simeonov E, Beckett W, Donnai D and Tassabehji M: Autosomal dominant inheritance of Williams-Beuren syndrome in a father and son with haploinsufficiency for FKBP6. Clin Dysmorphol 14: 61-65, 2005. 
2. Osborne LR, Li M, Pober B, Chitayat D, Bodurtha J, Mandel A, Costa T, Grebe T, Cox S, Tsui LC and Scherer SW: A 1.5 millionbase pair inversion polymorphism in families with WilliamsBeuren syndrome. Nat Genet 29: 321-325, 2001.

3. Tassabehji M: Williams-Beuren syndrome: a challenge for genotype-phenotype correlations. Hum Mol Genet 12: R229-R237, 2003.

4. Dutly F and Schinzel A: Unequal interchromosomal rearrangements may result in elastin gene deletions causing the WilliamsBeuren syndrome. Hum Mol Genet 5: 1893-1898, 1996.

5. Valero MC, de Luis O, Cruces J and Perez Jurado LA: Finescale comparative mapping of the human $7 \mathrm{q} 11.23$ region and the orthologous region on mouse chromosome 5G: the low-copy repeats that flank the Williams-Beuren syndrome deletion arose at breakpoint sites of an evolutionary inversion(s). Genomics 69: 1-13, 2000

6. Baumer A, Dutly F, Balmer D, Riegel M, Tukel T, KrajewskaWalasek M and Schinzel AA: High level of unequal meiotic crossovers at the origin of the 22q11.2 and 7q11.23 deletions. Hum Mol Genet 7: 887-894, 1998.

7. Perez Jurado LA, Peoples R, Kaplan P, Hamel BC and Francke U: Molecular definition of the chromosome 7 deletion in Williams syndrome and parent-of-origin effects on growth. Am J Hum Genet 59: 781-792, 1996.

8. Peoples R, Franke Y, Wang YK, Perez-Jurado L, Paperna T, Cisco $\mathrm{M}$ and Francke U: A physical map, including a BAC/PAC clone contig, of the Williams-Beuren syndrome - deletion region at 7q11.23. Am J Hum Genet 66: 47-68, 2000.

9. Bayes M, Magano LF, Rivera N, Flores R and Perez Jurado LA: Mutational mechanisms of Williams-Beuren syndrome deletions. Am J Hum Genet 73: 131-151, 2003.

10. Korenberg JR, Chen XN, Hirota H, Lai Z, Bellugi U, Burian D, Roe B and Matsuoka R: VI. Genome structure and cognitive map of Williams syndrome. J Cogn Neurosci 12 (suppl 1): 89-107, 2000 .

11. Karmiloff-Smith A, Grant J, Ewing S, Carette MJ, Metcalfe K, Donnai D, Read AP and Tassabehji M: Using case study comparisons to explore genotype-phenotype correlations in Williams-Beuren syndrome. J Med Genet 40: 136-140, 2003.

12. Botta A, Novelli G, Mari A, Novelli A, Sabani M, Korenberg J, Osborne LR, Digilio MC, Giannotti A and Dallapiccola B: Detection of an atypical 7q11.23 deletion in Williams syndrome patients which does not include the STX1A and FZD3 genes. J Med Genet 36: 478-480, 1999.

13. Heller R, Rauch A, Lüttgen S, Schröder B and Winterpacht A: Partial deletion of the critical $1.5 \mathrm{Mb}$ interval in Williams-Beuren syndrome. J Med Gen 40: e99, 2003.

14. Somerville MJ, Mervis CB, Young EJ, Seo EJ, del Campo M, Bamforth S, Peregrine E, Loo W, Lilley M, Perez-Jurado LA, Morris CA, Scherer SW and Osborne LR: Severe expressivelanguage delay related to duplication of the Williams-Beuren locus. N Engl J Med 353: 1694-1701, 2005.

15. Laccone F, Junemann I, Whatley S, Morgan R, Butler R, Huppke P and Ravine D: Large deletions of the MECP2 gene detected by gene dosage analysis in patients with Rett syndrome. Hum Mutat 23: 234-244, 2004.

16. Boehm D, Herold S, Kuechler A, Liehr T and Laccone F: Rapid detection of subtelomeric deletion/duplication by novel realtime quantitative PCR using SYBR-green dye. Hum Mutat 23: 368-378, 2004

17. Wilke K, Duman B and Horst J: Diagnosis of haploidy and triploidy based on measurement of gene copy number by realtime PCR. Hum Mutat 16: 431-436, 2000.

18. Howald C, Merla G, Digilio MC, Amenta S, Lyle R, Deutsch S, Choudhury U, Bottani A, Antonarakis SE, Fryssira H, Dallapiccola B and Reymond A: Two high-throughput technologies to detect segmental aneuploidies identify new WilliamsBeuren Syndrome patients with atypical deletions. J Med Genet, 2005.

19. Olney PN, Kean LS, Graham D, Elsas LJ and May KM: Campomelic syndrome and deletion of SOX9. Am J Med Genet 84: 20-24, 1999.

20. Perez Jurado AL: Williams-Beuren syndrome: a model of recurrent genomic mutation. Horm Res 59 (suppl 1): 106-113, 2003

21. Morris CA and Mervis CB: Williams syndrome and related disorders. Annu Rev Genomics Hum Genet 1: 461-484, 2000.

22. Nakamura N, Toba S, Hirai M, Morishita S, Mikami T, Konishi M, Itoh $\mathrm{N}$ and Kurosaka A: Cloning and expression of a brain-specific putative UDP-GalNAc: polypeptide Nacetylgalactosaminyltransferase gene. Biol Pharm Bull 28: 429-433, 2000
23. Wu YQ, Lin $X$, Liu CM, Jamrich $M$ and Shaffer LG: Identification of a human brain-specific gene, calneuron 1, a new member of the calmodulin superfamily. Mol Genet Metab 72: 343-350, 2001.

24. Nicolis E, Bonizzato A, Assael BM and Cipolli M: Identification of novel mutations in patients with Shwachman-Diamond syndrome. Hum Mutat 25: 410, 2005.

25. Antonin W, Franz C, Haselmann U, Antony C and Mattaj IW: The integral membrane nucleoporin pom 121 functionally links nuclear pore complex assembly and nuclear envelope formation. Mol Cell 17: 83-92, 2005.

26. Antonell A, de Luis O, Domingo-Roura X and Perez-Jurado LA: Evolutionary mechanisms shaping the genomic structure of the Williams-Beuren syndrome chromosomal region at human 7q11.23. Genome Res 15: 1179-1188, 2005.

27. Doll A and Grzeschik KH: Characterization of two novel genes, WBSCR20 and WBSCR22, deleted in Williams-Beuren syndrome. Cytogenet Cell Genet 95: 20-27, 2001

28. Pezzi N, Prieto I, Kremer L, Perez Jurado LA, Valero C, Del Mazo J, Martinez A-C and Barbero JL: STAG3, a novel gene encoding a protein involved in meiotic chromosome pairing and location of STAG3-related genes flanking the Williams-Beuren syndrome deletion. FASEB J 14: 581-592, 2000 .

29. Osborne LR, Herbrick JA, Greavette T, Heng HH, Tsui LC and Scherer SW: PMS2-related genes flank the rearrangement breakpoints associated with Williams syndrome and other diseases on human chromosome 7. Genomics 45: 402-406, 1997.

30. Hultqvist M and Holmdahl R: Ncf1 (p47phox) polymorphism determines oxidative burst and the severity of arthritis in rats and mice. Cell Immunol 233: 97-101, 2005.

31. Hirota H, Matsuoka R, Chen XN, Salandanan LS, Lincoln A, Rose FE, Sunahara M, Osawa M, Bellugi U and Korenberg JR: Williams syndrome deficits in visual spatial processing linked to GTF2IRD1 and GTF2I on chromosome 7q11.23. Genet Med 5: $311-321,2003$.

32. Tipney HJ, Hinsley TA, Brass A, Metcalfe K, Donnai D and Tassabehji M: Isolation and characterisation of GTF2IRD2, a novel fusion gene and member of the TFII-I family of transcription factors, deleted in Williams-Beuren syndrome. Eur J Hum Genet 12: 551-560, 2004.

33. Danoff SK, Taylor HE, Blackshaw S and Desiderio S: TFII-I, a candidate gene for Williams syndrome cognitive profile: parallels between regional expression in mouse brain and human phenotype. Neuroscience 123: 931-938, 2004.

34. Ranheim EA, Kwan HC, Reya T, Wang YK, Weissman IL and Francke U: Frizzled 9 knock-out mice have abnormal B-cell development. Blood 105: 2487-2494, 2005.

35. Jones MH, Hamana N, Nezu J and Shimane M: A novel family of bromodomain genes. Genomics 63: 40-45, 2000

36. Jadayel DM, Osborne LR, Coignet LJ, Zani VJ, Tsui LC, Scherer SW and Dyer MJ: The BCL7 gene family: deletion of BCL7B in Williams syndrome. Gene 224: 35-44, 1998.

37. Perez Jurado LA, Wang YK, Francke U and Cruces J: TBL2, a novel transducin family member in the WBS deletion: characterization of the complete sequence, genomic structure, transcriptional variants and the mouse ortholog. Cytogenet Cell Genet 86: 277-284, 1999.

38. Merla G, Howald C, Antonarakis SE and Reymond A: The subcellular localization of the ChoRE-binding protein, encoded by the Williams-Beuren syndrome critical region gene 14, is regulated by 14-3-3. Hum Mol Genet 13: 1505-1514, 2004.

39. Merla G, Ucla C, Guipponi M and Reymond A: Identification of additional transcripts in the Williams-Beuren syndrome critical region. Hum Genet 110: 429-438, 2002.

40. Bennett MK, Calakos N and Scheller RH: Syntaxin: a synaptic protein implicated in docking of synaptic vesicles at presynaptic active zones. Science 257: 255-259, 1992.

41. Rangel LB, Agarwal R, D'Souza T, Pizer ES, Alo PL, Lancaster WD, Gregoire L, Schwartz DR, Cho KR and Morin PJ: Tight junction proteins claudin-3 and claudin-4 are frequently overexpressed in ovarian cancer but not in ovarian cystadenomas. Clin Cancer Res 9: 2567-2575, 2003.

42. Morita K, Furuse M, Fujimoto K and Tsukita S: Claudin multigene family encoding four-transmembrane domain protein components of tight junction strands. Proc Natl Acad Sci USA 96: 511-516, 1999 .

43. Ewart AK, Jin W, Atkinson D, Morris CA and Keating MT: Supravalvular aortic stenosis associated with a deletion disrupting the elastin gene. J Clin Invest 93: 1071-1077, 1994. 
44. Frangiskakis JM, Ewart AK, Morris CA, Mervis CB, Bertrand J, Robinson BF, Klein BP, Ensing GJ, Everett LA, Green ED, Proschel C, Gutowski NJ, Noble M, Atkinson DL, Odelberg SJ and Keating MT: LIM-kinase 1 heterozygosity implicated in impaired visuospatial constructive cognition. Cell 86: 59-69, 1996.

45. Shabahang S, Liu YH, Huwiler A and Pfeilschifter J: Identification of the LIM kinase-1 as a ceramide-regulated gene in renal mesangial cells. Biochem Biophys Res Commun 298: 408-413, 2002.

46. Bordeleau ME, Matthews J, Wojnar JM, Lindqvist L, Novac O, Jankowsky E, Sonenberg N, Northcote P, Teesdale-Spittle P and Pelletier J: Stimulation of mammalian translation initiation factor eIF4A activity by a small molecule inhibitor of eukaryotic translation. Proc Natl Acad Sci USA 102: 10460-10465, 2005.

47. Fliegauf M, Stock M, Berg T and Lubbert M: Williams-Beuren syndrome critical region-5/non-T-cell activation linker: a novel target gene of AML1/ETO. Oncogene 23: 9070-9081, 2004.
48. Ellison V and Stillman B: Biocheterocal characterization of DNA damage checkpoint complexes: clamp loader and clamp complexes with specificity for 5 ' recessed DNA. PLoS Biol 1: E33, 2003.

49. Hoogenraad CC, Koekkoek B, Akhmanova A, Krugers H, Dortland B, Miedema M, van Alphen A, Kistler WM, Jaegle M, Koutsourakis M, Van Camp N, Verhoye M, van der Linden A, Kaverina I, Grosveld F, De Zeeuw CI and Galjart N: Targeted mutation of Cyln2 in the Williams syndrome critical region links CLIP-115 haploinsufficiency to neurodevelopmental abnormalities in mice. Nat Genet 32: 116-127, 2002.

50. Hoogenraad CC, Akhmanova A, Galjart N and De Zeeuw CI: LIMK1 and CLIP-115: linking cytoskeletal defects to Williams syndrome. Bioessays 26: 141-150, 2004. 